\title{
Lucio's phenomenon: another case reported in Brazil *
}

\author{
Fenômeno de Lúcio: mais um caso relatado no Brazil
}

\author{
Rodrigo Monteiro ${ }^{1}$ \\ Marcelo Guimarães Tiezzi ${ }^{3}$ \\ Claudia Cardoso Macedo de Oliveira ${ }^{1}$
}

\author{
Marilda Aparecida Milanez Morgado de Abreu² \\ Eduardo Vinícios Mendes Roncada ${ }^{1}$ \\ Luciena Cegatto Martins Ortigosa ${ }^{4}$
}

\begin{abstract}
Lucio's phenomenon is defined as a variant of type 2 leprosy reaction. It is a rare event, occurring in the evolution of leprosy of Lucio and other forms of lepromatous leprosy. It has an exacerbated proliferation of Hansen bacilli in its pathophysiology, which invade blood vessel walls and injure endothelial cells, causing endothelial proliferation and decreasing the vascular lumen. This fact, associated with inflammatory reactions and changes in the coagulation system causes vascular thrombosis, ischemia, infarction and tissue necrosis, leading to the histopathological characteristic of the phenomenon. We report a case of lepromatous leprosy with irregular treatment that developed Lucio's phenomenon. Treatment with multidrug therapy, antibiotics, steroids and thalidomide achieved a favorable outcome. Keywords: Blood coagulation; Blood coagulation disorders; Drug therapy; Erythema nodosum; Leprosy, lepromatous; Therapeutics; Thrombosis
\end{abstract}

\begin{abstract}
Resumo: Define-se o fenômeno de Lúcio como uma variante da reação hansênica do tipo 2. Evento raro, que ocorre na evolução da hanseníase de Lúcio e de outras formas de hanseníase virchowiana. Tem na sua fisiopatologia uma proliferação exacerbada dos bacilos de Hansen, que invadem a parede dos vasos sanguíneos e agridem as células endoteliais, causando proliferação endotelial e diminuição do lúmen vascular, fato este, que associado a reações inflamatórias e a alterações no sistema da coagulação, causa trombose vascular, isquemia, infarto e necrose tecidual, gerando as alterações histopatológicas características do fenômeno. Relatamos um caso de hanseníase virchowiana, com tratamento irregular, que desenvolveu o fenômeno de Lúcio. Recebeu tratamento com poliquimioterapia, antibióticos, corticosteróide e talidomida, evoluindo com desfecho clínico favorável.

Palavras-chave: Coagulação sanguínea; Eritema nodoso; Hanseníase Virchowiana; Quimioterapia; Terapêutica; Transtornos da coagulação sanguínea; Trombose
\end{abstract}

Received on 28.12.2010.

Approved by the Advisory Board and accepted for publication on 20.05.2011.

* Study carried out at the the Dermatology Service, Hospital Regional de Presidente Prudente - Universidade do Oeste Paulista (HRPP-UNOESTE) - Presidente Prudente (SP), Brazil.

Conflict of interest: None

Financial funding: None

Gradute student in Dermatology - Resident physician of the Dermatology Service, Hospital Regional de Presidente Prudente - Universidade do Oeste Paulista (HRPP- UNOESTE) - Presidente Prudente (SP), Brazil.

PhD, Professor - Head of the Dermatology Service, Hospital Regional de Presidente Prudente - Universidade do Oeste Paulista (HRPP-UNOESTE) - Presidente Prudente (SP), Brazil.

Specialist in Pathological Anatomy - Pathologist physician of the Laboratório de Anatomia Patológica e Citologia (LAPC) responsible for dermatopathology at the Hospital Regional de Presidente Prudente - Universidade do Oeste Paulista (HRPP-UNOESTE) - Presidente Prudente (SP), Brazil.

Master's degree in Dermatology - Assistant Professor of the Dermatology Service, Hospital Regional de Presidente Prudente - Universidade do Oeste Paulista (HRPP-UNOESTE) - Presidente Prudente (SP), Brazil. 


\section{INTRODUCTION}

Lucio's phenomenon represents a variant of type 2 leprosy reaction that has its clinical presentation characterized as "necrotizing erythema". This phenomenon was first described by Lúcio and Alvarado in 1852, in Mexico, and was so named by Lapatí and Zamora, in 1948. ${ }^{1}$ Its occurrence is restricted to the leprosy of Lucio, which is the pure and primitive virchowian form, as well as the other forms of virchowian leprosy. ${ }^{1,2}$ Leprosy of Lucio is a variant of virchowian leprosy (VL), also described by Lúcio and Alvarado, where erythematous-violaceous maculae and blisters - hemorrhagic or not - may appear, but its main characteristic is a diffuse cutaneous infiltration, without nodule formation, generating a brilliant, moist and myxedematous complexion, imparting a healthy aspect to the patient. As a result of these characteristics it was also called "Pretty Leprosy". It was in the course of Leprosy of Lucio that the onset of Lucio's phenomenon (LP) was described. ${ }^{2,3,4}$ The few cases reported in the international literature emphasize the rarity of the event. We report a VL case during irregular treatment, which progressed with LP and achieved a favorable outcome.

\section{CASE REPORT}

A.D.S., male, 61 years old, retired, born and resident in Teodoro Sampaio - SP. The patient was admitted to the emergency room of our hospital with history of unmeasured fever for 15 days, associated with prostration, hyporexia and painful skin lesions. Family members mentioned that he had diabetes mellitus type 2, was an alcoholic, tobacco user and was being treated for VL with the multibacillary, multidrug therapy (MDT) recommended by the World Health Organization for approximately 6 months, but he followed the treatment irregularly and did not take the medications for long periods of time. The physical examination showed his general health was regular, he was dehydrated $++/ 4$, pale $+++/ 4$, prostrate, afebrile, eupneic and anicteric, without other alterations. The dermatological examination revealed livedoid maculae and painful, polymorphic ecchymotic maculae, some of them topped by whole and tense blisters with hyaline content. There were infiltrated ulcerated plaques, with irregular outlines and ill-defined borders, in addition to small erythematous subcutaneous nodules. Most of the lesions presented an ulcerated surface covered by scarce granulation tissue, purulent fibrin material, sometimes hemorrhagic and honeycolored crusts. The lesions were distributed on the upper, anterior and posterior portions of the thorax and on the proximal portion of upper limbs (Figures 1 and 2). The extremities were not involved. The hemogram revealed severe anemia and intense leuko-

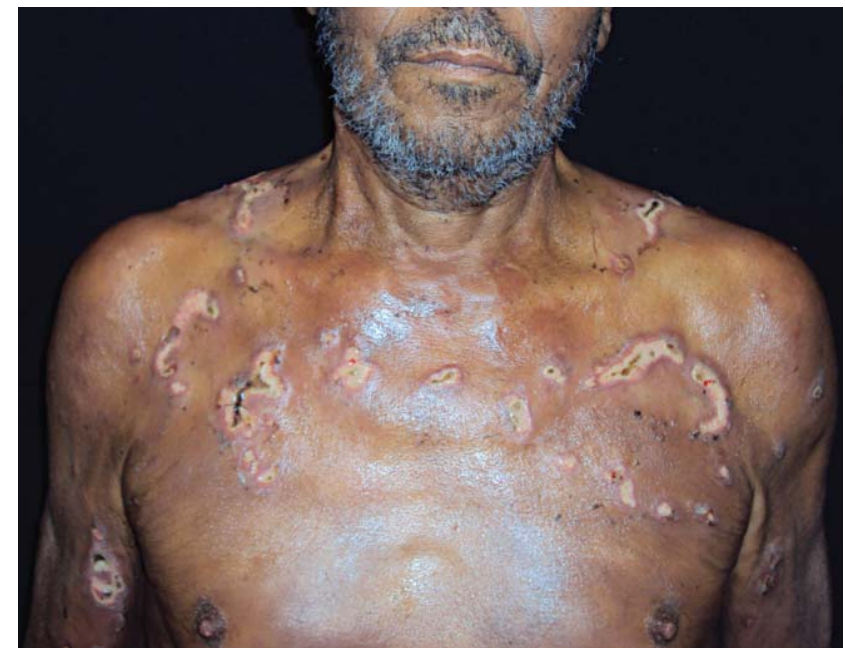

FigurE 1: The patient has lesions in rare locations, concentrated in the upper third of the anterior and posterior chest and upper limb root, sparing the legs and face. In this image we observe the various LP lesions, such as ecchymotic and livedoid skin maculae, infiltrated ulcerated plaques with scarce granulation tissue and purulent fibrin material

cytosis (hemoglobin: $5.9 \mathrm{~g} / \mathrm{dL}$, hematocrit: $18.6 \%$, MCV: $89.8 \mathrm{fL}, \mathrm{MCH}$ : $28.4 \mathrm{pg}$, leukocytes: 54,800 with $23 \%$ rods). It was confirmed that the patient had VL through contact with the original Basic Health Unit and the diagnostic hypothesis of type 2 leprosy reaction, LP variant was raised. This hypothesis was confirmed by the histopathological examination of the cutaneous lesion biopsy, which showed extensive areas of necrosis and suppuration in the dermis and subcutaneous regions, with thrombosed blood ves-

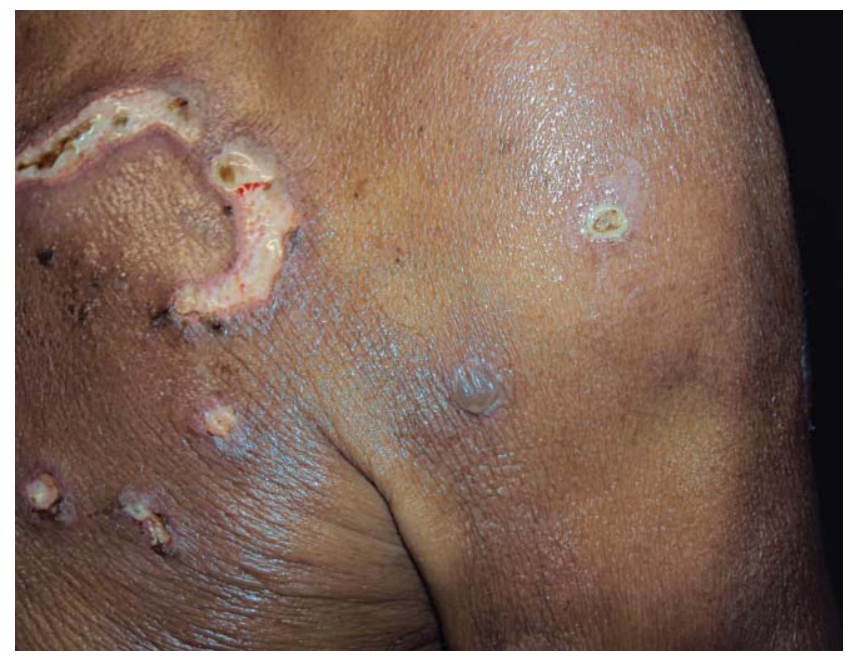

FigURE 2: With greater photo enlargement the ecchymotic maculae are well characterized, some topped by a bubble full of hyaline content, in addition to infiltrated ulcerated plaques covered by scarce granulation tissue, some of them with hemorrhagic spots and honey-colored scabs 
sels in their midst. By means of Fite-Faraco staining were detected alcohol-acid resistant bacilli (AARB) in the neighborhood of these vessels, within their walls, invading endothelial cells and the vascular lumen, besides focal areas of histiocyte proliferation, with ample xanthomatous cytoplasm (Figures 3, 4 and 5). The patient received clinical support and was treated with antibiotics (ciprofloxacin and clindamycin), prednisone $0.5 \mathrm{mg} / \mathrm{kg} / \mathrm{day}$ and thalidomide $400 \mathrm{mg} /$ day. As he presented important anemia of etiology that remains to be clarified, he was evaluated by the hematologist and the possibility of hemolysis was excluded, with glucose-6-phosphate-dehydrogenase within normal limits. Consequently, MDT was resumed, following the multibacillay scheme. The patient was discharged after 15 days of hospitalization, with significant improvement demonstrated both clinically and in laboratory tests (hemoglobin: $9.7 \mathrm{~g} / \mathrm{dL}$, hematocrit: $29.4 \%$, MCV: $89.1 \mathrm{fL}, \mathrm{MCH}: 29,6 \mathrm{pg}$, leukocytes: 19,900 with $04 \%$ rods). Outpatient clinic follow-up was done at 30,90 and 120 days after discharge from the hospital; at the first follow-up appointment, 30 days later, he already presented cutaneous atrophy from scarring in lesion sites. Prednisone and thalidomide doses were gradually decreased (Figure 6). He was discharged from outpatient clinic follow-up after 120 days post-hospital discharge monitoring and returned to the original Basic Health Unit using only MDT, following the multibacillay scheme and without any sign or symptom of reaction recidivation.

\section{DISCUSSION}

Lucio's phenomenon was originally described as an acute event in Lucio's leprosy evolution, characteri-

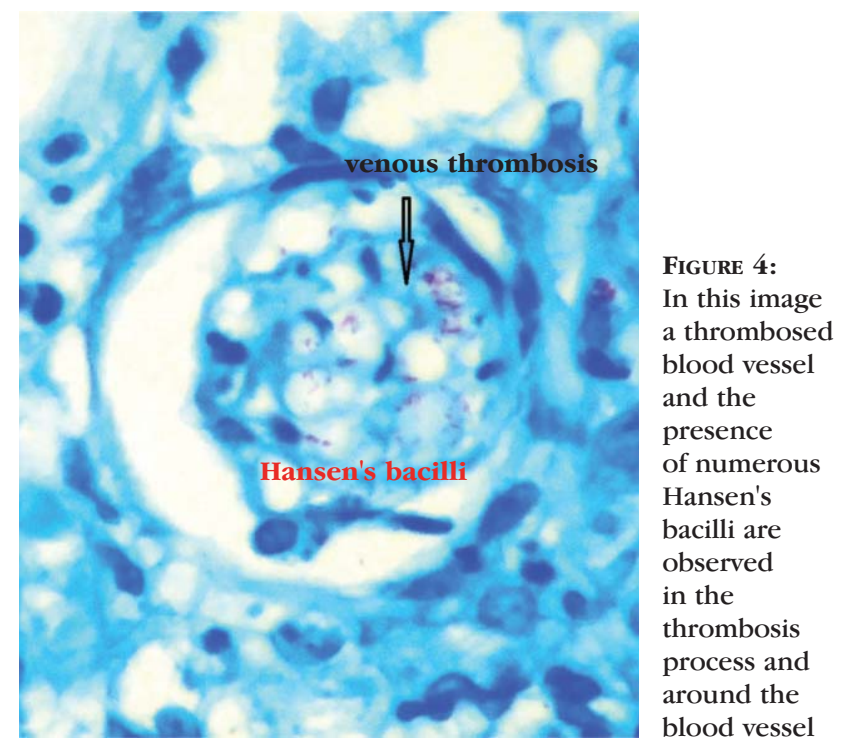

zed by the onset of erythematous-violaceous maculae and infiltrated plaques the progress with central necrosis followed by ulceration, affecting in ascending order of frequency: feet, legs, hands, forearms, thighs, arms and, rarely,the trunk and face, leaving atrophic and stellar scars. ${ }^{5,6}$ Our patient only presented involvement of the trunk and root of upper limbs. Later on the presence of blisters, hemorrhagic or not, were observed, which caused the characteristic ulceration when they broke. ${ }^{7,8}$ They frequently occur in patients who were never treated or in those who have followed treatment irregularly, but they are not an exclusive event of Lucio's leprosy and may occur in other VL forms. ${ }^{6,9}$

The alterations detected in laboratory exams

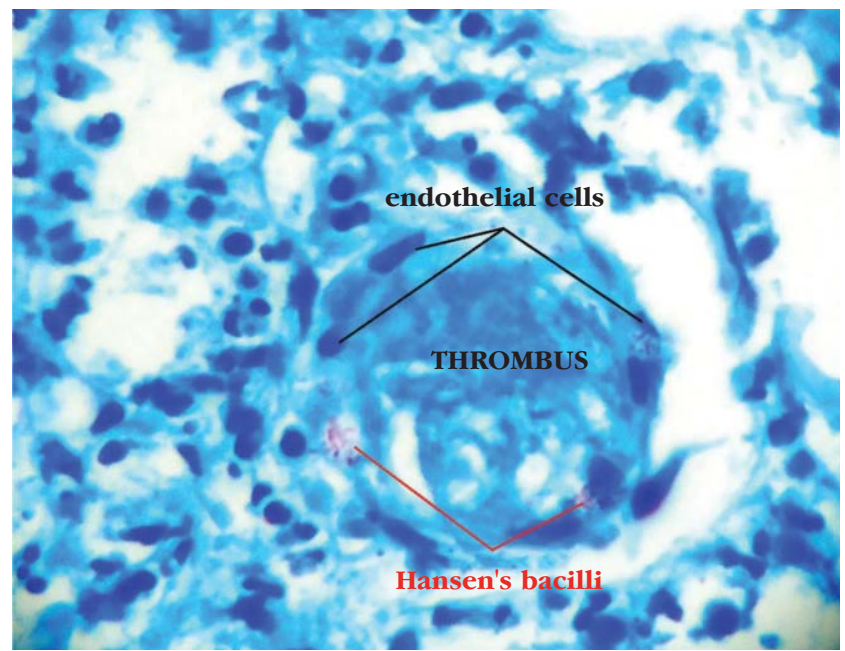

Figure 5: In another image there is a blood vessel completely occluded by a thrombus, once again characterized by the presence of Hansen's bacilli invading the vessel, endothelial cells and lumen of the vessel 


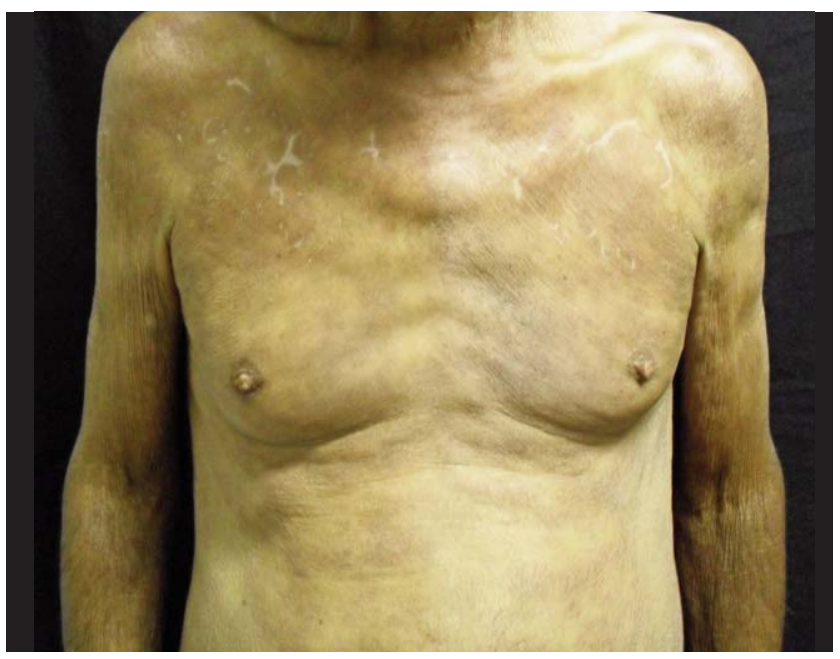

Figure 6: In the first outpatient return, 30 days after hospital discharge, there is complete remission of lesions and the presence of stellar and hypopigmented atrophic scars, characteristic scar patterns of Lucio's phenomenon

described in LP are: anemia, a high erythrocyte sedimentation rate, hypoalbuminemia, hypergamaglobulinemia, false-positive serological reactions for syphilis, positive reumatoid factor, mixed type cryoglobulins, circulating immune complexes and hypocomplementemia. Comorbidities, such as secondary infections, malnutrition and others that may accompany LP, are also responsible for some of these alterations. ${ }^{6}$ However, high levels of leukocytosis is a characteristic finding of FL, described in many other studies. ${ }^{10}$ The laboratory findings should be carefully investigated before drawing conclusions.

Among the explanatory hypotheses for LP, the most often accepted is the one that supposes it is an intense congestive vascular reaction, habitually hemorrhagic, leading to tissue necrosis. ${ }^{11}$ Such reaction would be immune-mediated, cytokine-dependent, occurring in sites where there is inflammatory reaction, without significant expression of lymphocytes $\mathrm{T}$, mediated by interleukin 1(IL-1) and by the tumoral necrosis factor (TNF). Secretion of TNF and IL-1 by activated macrophages would stimulate endothelial cells to produce prostaglandins, interleukin 6 (IL-6) and a procoagulation protein (factor III), triggering a coagulation cascade with thrombi formation in capillary lumen. This causes ischemia, infarction and necrosis of the affected tissues in a localized manner, but in more severe forms may lead to disseminated intravascular coagulation. ${ }^{12}$ Several LP triggering factors are described, such as certain intercurrent infections (streptococcal, cryptococcal, respiratory), drugs (iodide and chaulmoogra oil) and pregnancy ${ }^{3}$. Quismorio et al., in 1978, verified the presence of complement and immunoglobulin on the walls of dermal blood vessels and surrounding areas, in addition to circulating immune complexes and serum cryoglobulins of the mixed type containing IgM, IgG, IgA, C3 and C1q.1, 13

Azulay-Abulafia L., et al., in 2005, published an extensive review of the literature on the histopathological aspects of the LP described by several authors between the years of 1950 and 1993. This publication revealed great disagreement among the authors regarding the presence or absence of leukocytoclastic vasculitis in LP, as well as regarding the terminology employed, which is not uniform. Nevertheless, other characteristics, such as: presence of AARB trough the dermis or surrounding the blood vessels, invading the vascular wall and endothelial cells, decreasing vascular lumen by endothelial proliferation or total occlusion by thrombi, thrombosis of several venous systems suggesting involvement of the coagulation system, leakage of red blood cells, inflammatory infiltrate with lymphocytes and neutrophils, in addition to perivascular perivascular histiocytic granulomas were common characteristics in the great majority of studies analyzed. ${ }^{1,2,3,6,7,8,10,14,15}$ Some authors defend the thesis that vessels of all calibers may be affected, those of greater caliber being related to greater clinical exuberance of LP, as well as. when there is total occlusion, to greater severity. Moreover, the same authors, based on their results, affirm that endothelial cells and vascular walls are not invaded only by the M. leprae, but also by activated macrophages, usually with bacilli clumps in their interior.

In short, according to the international literature, three criteria are adopted as the rule for LP definition: cutaneous ulceration, vascular thrombosis and blood vessel walls invasion by Hansen's bacillus.

Due to the small quantity of LP cases studied and reported in the international literature, there is no consensus regarding the best treatment for this reaction. There are reports that go from balanced meals and local hygiene only or the use of isolated drugs taken orally, such as dapsone, clofazimine, corticoids, thalidomide, among others, to the utilization of a wide choice of therapies, with varied outcomes of therapeutic success or failure. ${ }^{3,6,15}$ Currently, as new clarifications regarding the physiopathology of LP have shown that intercurrent infections may be a trigger and precipitate the reaction, an adequate treatment is recommended, in association with specific therapy for infection by Hansen's bacillus.

LP is a rare event that may reach severe proportions and cause death by disseminated intravascular coagulation and/or septicemia. Of the few cases reported worldwide, some are from Brazil. This is one more case confirmed in our country, that fortunately had a favorable outcome. 


\section{REFERENCES}

1. Helmer K A, Fleishfresser I, Kucharski-Esmanhoto L D, Neto J F, Santamaria J R. Fenômeno de Lúcio (eritema necrosante) na gestação. An Bras Dermatol. 2004;79:205-10.

2. Vargas-Ocampo F. Diffuse leprosy of Lucio and Latapí: a histologic study. Lepr Rev. 2007;78:248-60.

3. Azulay-Abulafia L, Spinelli L. Revisiting Lucio's leprosy and Lucio's phenomenon. Med Cutan Iber Lat Am. 2005;33:125-33.

4. Choon SE, Tey KE. Lucio's phenomenon: a report of three cases seen in Johor, Malaysia. Int J Dermatol. 2009;48:984-8.

5. Alvorado L R. Opusculo sobre el mal de San Lazaro o elefantiasis de Los Griegos (1851). Dermatol Ver Mex. 1978;22:93-101.

6. Costa IM, Kawano LB, Pereira CP, Nogueira LS. Lucio's phenomenon: a case report and review of the literature. Int J Dermatol. 2005;44:566-71.

7. Rea TH, Levan NE. Current concepts in the immunology of leprosy. Arch Dermatol. 1977;113:345-52

8. Benard G, Sakai-Valente NY, Bianconcini Trindade MA. Concomitant Lucio phenomenon and erythema nodosum in a leprosy patient: clues for their distinct pathogeneses. Am J Dermatopathol. 2009;31:288-92.

9. DA Silva JM. 8TH International Congress of Leprology, Rio de Janeiro, 1963. Report of the panel on leprosy reaction. Lepr Rev. 1964;35:Suppl 37-40.

10. Pereira Jr AC. Hanseníase de Lúcio. An Bras Dermatol. 1993:68:33-40.

11. Lapatí F R, Chevéz-Zamora A. La lepra manchada de Lucio. Rev Dermatol Mex. 1978:22:102-7.

12. Oppenheim J J, Ruscetti F W, Faltynek C. Citokines. In: Stites DP, Terr AL, Parslow TG. Basic and clinical immunology. 8th ed. Norwalk: Pretence-Hall Int. Inc; 1994. p.105-23.
13. Quismorio FP Jr, Rea T, Chandor S, Levan N, Friou GJ. Lucio's phenomenon: an immune complex deposition syndrome in lepromatous leprosy. J Clin Immun Immunopath. 1978;9:184-93.

14. Magaña M, Fernández-Díez J, Magaña ML. Lucio's phenomenon is a necrotizing panvasculitis: mostly a medium-sized granulomatous arteritis. Am J Dermatopathol. 2008;30:555-60.

15. Buffon LP, Leal R, Vidigal MR, Gatti TSR, Pires MC, Reis VMS. Fenômeno de Lúcio (eritema necrosante) na gestação: relato de caso e revisão da literatura. An Bras Dermatol. 2001;76:441-8.

\author{
MAILING ADDRESS: \\ Rodrigo Monteiro \\ Praça Nossa Senhora Aparecida, 114 - Conj. 1302. \\ Vila Marcondes \\ 19030-120 Presidente Prudente, SP \\ E-mail:rodrigomt@botmail.com
}

How to cite this article: Monteiro R, Abreu MAMM, Tiezzi MG, Roncada EVM, Oliveira CCM, Ortigosa LCM. Lucio's phenomenon: another case reported in Brazil. An Bras Dermatol. 2012;87(2)296-300. 